\title{
HUBUNGAN INTERNASIONAL DAN HAM DALAM PERSPEKTIF ISLAM.
}

\author{
Kamsi \\ Fak. Syariah dan Hukum UIN Sunan Kalijaga \\ Email: kamsijanturan@gmail.com
}

\section{Abstract}

This paper elaborates intemational relationship and buman rights in the Islamic perspective. The principle of intermational relations in Islam is an etemal peace that is fundamental rights of every nation, except in an emergeng. Then, intermational relation turns into a war. If war is indeed to be done, the war in Islam is a defending war and does not violate buman rights.

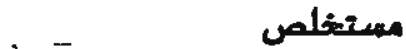

هذه المقالة باحِثة عن رابطة عالمية و حقوق الإنسانية في نظرة الإنسالام. أن مبدى رابطة عالمية

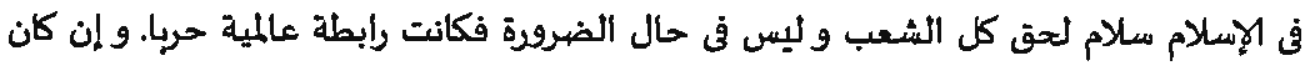
الحرب شيناً يجيب في العمل فكان الحربّ حرب الدفاع ولا مخالفة لحقوق الإنسانية.

Keywords. Hubungan Internasional, HAM, Islam, Darul Harbi

\section{A. Pendahuluan}

Ilmu Hubungan Internasional merupakan studi yang interdisipliner sehingga membuka segala kemungkinan persinggungan dengan kajian di luar studi ini, dan tidak ketinggalan juga masalah hak asasi manusia. Menggeluti studi Hubungan Internasional yang termasuk daiam ranah ilmu sosial maka mau tidak mau kita akan mendapati bahwasanya ilmu ini berkiblat terhadap Barat. Realitas ini membuat diskusi wacana yang ada "dikendalikan" oleh Barat sehingga 
wacana "pinggiran" benar-benar termarginalkan, dengan kata lain ketika para akademisi menganalisis suatu fenomena sosial tertentu, pandangan dunia Barat berada pada posisi bird-eye. Maka tepatlah apa kata Michel Foucault, bahwa pengendali power memegang peranan penting dalam proses diskursus yang ada. $^{1}$

Dalam studi Islam biasanya terma politik ini disejajarkan dengan terma siyasah, yang secara etimologi berarti mengatur sesuatu dengan cara yang membawa kemaslahatan. ${ }^{2}$ Dalam terminologi figh dikenal dengan figb siyasab atau siyasah syariyah, yaitu sebuah pranata untuk mengatur urusan negara dan urusan umat sesuai dengan syari at islamiyyah agar terwujud kemaslahatan dan terhindar dari kemadaratan. ${ }^{3}$ Secara lebih rinci, bidang kajiannya adalah siyasab dusturiyab (perundang-undangan), siyasab maliyah (perekonomian), siyasab dauliyah (hubungan Internasional).

Kajian tentang hubungan internasional dalam fiqh siyasah meskipun merupakan tema yang tergolong tua karena ini produk dari khazanah Islam klasik dan pertengahan. Sehingga secara praksis persoalan ini menjadi persolan problematik apabila dihadapkan dengan konsep negara bangsa yang dianut oleh bebrapa negeri-negeri muslim di era modern. Secara teoretik Hubungan Internasional telah hadir beberapa teori besar dalam bidang kajian atau ilmu ini dengan memperhatikan paling tidak kepada lima nilai dasar sosiał yang biasanya dijaga oleh negara: keamanan, kebebasan, ketertiban, keadilan dan kesejahteraan. Ini merupakan nilai-nilai yang sangat. fondamental bagi manusia yang harus mereka lindungi atau jamin dengan cara apapun ${ }^{4}$.

Teori besar sebagaimana dimaksud di atas adalah: diawali dari perdebatan besar pertama antara Liberalisme (1920) dan Realisme (1930-1950), perdebatan besar kedua anatara Pendekatan Tradisonal dan Behavioralis, perdebatan besar

${ }^{1}$ Mengkaji (Kembali) Identitas Studi Hubungan Internasional dari Perspektif Teologis: Sebuah Pembacaan Awal bustomimenggugat.blogspot.com/.../mengkaji-kembali-identitas-studi... Diakses tanggal 7 Nopember 2012.

2Ibnu Manzur, Lisanul 'Arab, (Beirut: Dar ash-Shadit, 1386/1968), VI: 108.

${ }^{3}$ Abd. Wahab Khallaf, As-Siyasah as-Syar iyah, (Kairo: Dar al-Ansar, 1977), hal. 4.

4Robert Jackson \& Georg Sorensen, Pengantar Studi Hubungan Intemasional, alih bahasa Dadan Suryaputra, (Yogyakarta: Pustaka Pelajar, 2005), hal. 3. 
ketiga anatara Realisme/Neorealisme, Liberalisme/Neoliberalisme dan Neo-Marxisme, dan perdebatan besar berikutnya adalah anatara Tardisi yang telab mapan dan suara-suara baru. Selain dua teori besar di atas masih ada dua teori lagi yaitu: teori Masyarakat Intemasional dan teori Ekonomi Politik Intermasional. Dan bagaimanakah teori hubungan internasional dan HAM dalam Perspektif Islam ketika menghadapi dunia modern ini? Untuk menjawab persoalan ini penulis mensajikan beberapa hal sebagai berikut: mainstream tèori hubungan internasional, hubungan internasional dalam versi Islam.

\section{B. Mainstream Teori Hubungan Internasional}

Teori liberalis, adalah teori yang menekankan pada kebebasan, perdamaian dan kemajuan. Perdamaian meningkatkan kebebasan. Perdamaian juga menjadikan perubahan internasional yang progresif menjadi mungkin, yaitu peciptaan dunia yang lebih baik. Perdamaian dan perubahan progresif nyatanyata termasuk di antara nilai-nilai hubungan internasional yang paling fondamental dan merupakan ciri khas teori leberal dengan asumsi bahwa hubungan internasional dapat dicirikan sebagai dunia dimana negara-negara bekerja sama satu sama lain untuk memelihara perdamaian dan kebebasan serta mengejar perubahan progresif, ${ }^{5}$ yang fokusnya adalah hukum internasional, organisasi internasional, interdependensi, kerjasama, dan perdamaian.

Teori Realis, adalah teori hubungan internasional yang menekankan pada nilai keamanan politik kekuatan, konflik dan perang. Keamanan nyata-nyata merupakan salah satu nilai paling fundamental dalam hubungan internasional, dan menjadi ciri khas dari kaum realisme dengan asumsi bahwa hubungan negara dapat dicirikan sebaik-baiknya sebagai dunia yang di dalamnya negaranegara bersenjata bersaing dengan lawannya dan secara periodik berperang satu dengan yang lain. Dan fokus dari aliaran ini adalah politik porwer, keamana, agresi, konflik dan perang.

Pendekata Tradisonal, perdebatan yang hirau terhảdap metodologi yang berakar pada filsafat, sejarah dan hukum, dan dicirikan terutama dengan mendasarkan secara eksplisit atas pelaksanaan penilaian. Menempatkan

5Ibid., hal. 3-6. 
penilaian pada inti teori intemașional memberikan penekanan karakter normatif dari subyek yang pada intinya menimbulkan sebagian permasalahan moral yang sangat sulit bagi pólitisi maupun diplomat atau siapapun yang terlibat tidak adapat melepaskan diri, seperti penyebaran senjata nuklir dan pembenaran penggunaannya, intervensi militer di negara-negara merdeka. Fokus dari pendekatan ini adalah memahami norma dan nilai, penilaian dan pengetauan sejarah, adalah sama dengan fokus Masyarakat Internasional yang mendasarkan pada pada elemen-elemen: kiekuatan, kepentingan nasional (elemen realis); aturan, prosedure, hukum internasional (elemen liberal); hak asasi manusia universal, satu dunia untuk semua(elemen kosmopolitan). Teori Masyarakat Internasional, menghendaki bahwa ketertiban dan keadilan adalah nyata-nyata termasuk di antara nilai-nilai hubungan internasional yang paling fondamental. Teori ini berasumsi bahwa hubungan internasional dapat dicirikan secara baik sebagai dunia yang di dalamnya negara-negara secra sosial merupakan aktor yang bertanggung jawab dan memiliki kepentingan bersama dalam memelihara ketertiban internasional dan memajukan keadilan internasional.

Pendekatan behovior, adalah metode baru setelah perang dunia kedua, yaitu mengumpulkan data empiris tentang hubungan internasional yang kemudian digunakan untuk pengukuran, klasifikasi, genaralisasi, dan akhirnya pengesahan hipotesis-hipotesis terhadap prilaku yang dijelaskan secara ilmiah, karena itu pendekatan ini tidak menyediakan tempat bagi moralitas atau etika dalam studi Hubungan Internasional. Fokus dari pendekatan ini adalah menjelaskan hipotesa, pengumpulan data dan pengetahuan ilmiah.

Teori berikutnya adalah Ekonomi Politik Internasional, menurut teori ini bahwa kekakayaan dan kesejahteraan nyata-nyata termasuk di antara nilai-nilai hubungan internasional yang paling fondamental. Teori ini berasumsi bahwa hubungan internasional dapat dicirikan secara fondamental sebagai dunia sosioekonomi dan tidak hanya dunia politik dan militer. ${ }^{6}$ Pendekatan ini menggeser issu politik dan militer menuju issu sosial dan ekonomi. Teori ini juga menjadi jawaban atas teori Neo-Marxisme yang merupkan suatu upaya untuk menganalisa Dunia Ketiga dengan memakai alat analisis yang dikembangkan 
oloeh Karl Marx, teori ini memfokuskan pada: sistem dunia Kapitalis, ketergantugan dan keterbelakangan.

Liberalisme, realisme, masyarakat internasional dan ekonomi politik internasional adalah teori yasng telah dianggap mapan, kemudian muncul teori altematif sebagai suara-suara baru yang kemudian acapkali disebut dengan metodologi Pospositivisme. Fokus dari pendekatan tradisi yang telah mapan ini adalah: Ralisme/Neorealisme; Liberalisme/Neoliberalisme; masyarakat . intemasional dan ekonomi politik intemasional. Pada teori pospositivisme terfokus kepada metodologi-metodologi pos-positivisme dan isu-isu pos-pospositivisme.

\section{Hubungan Internasional dalam Islam}

Islam menjunjung tinggi buquq al-insaniyyab tanpa mengenal diskriminasi agama, warna kulit, dan kebangsaan. Selain itu, Islam juga mengakui hak milik pribadi, namun melarang menumpuk kekayaan, merampas, dan eksploitasi. Dengan kata lain, Islam mengakui hak milik perotangan, tetapi kepentingan sosial tidak boleh diabaikan. Islam menyetu agar seluruh umat manusia yang berlainan asal dan kebangsaan, warna kulit dan agamanya, menegakkan persaudaraan kemanusiaan secara menyeluruh, sehingga humanisme benarbenar terwujud dalam kehidupan umat manusia.

Itulah sebabnya sehingga Islam mengatur hubungan antata bangsa dan negara, baik di waktu damai maupun di waktu perang. Bahkan, sampai pada mendirikan badan internasional yang bertugas untuk menyelesaikan pertikaian yang terjadi di antara mereka. Apabila ada bangsa dan negara yang tidak mau tunduk, maka dengan kekuatan badan itu dapat memaksa menyelesaikan pertikaian-pertikaian yang terjadi, demi tergaknya kebenaran dan terjaminnya keadilan.

Prinsip-prinsip Islam mengenai hubungan internasional, lebih menekankan kepada nilai-nilai moral dan etika sebagai dasar HAM, katena tuntutan rasa kesadaran tunduk kepada norma-norma agama (akblaq al-karimab) dijadikan sebagai landasan utama bagi tegaknya Islam. Masalah HAM menjadi salah satu pusat perhatian dunia, dari dulu hingga kini, dan tetap menjadi isu aktual dalam 
berbagai peristiwa sosial, politik dan ekonomi, di tingkat nasional maupun internasional. Kaum muslim di seluruh dunia, sebagai bagian integral dari masyarakat internasional, mempunyai perhatian sungguh-sungguh terhadap isu global ini. Sebagai kelompok masyarakat yang memiliki warisan tradisi peradaban yang sangat kaya, kaum muslim tidak pernah diam memberikan. respon terhadap setiap isu penting yang berkembang dalam setiap zaman. Islam, adalah ajaran yang dinamis tidak stagnan. Islam selalu mendorong dan memacu umatnya mengeksplorasi untuk menemukan hal-hal baru demi kemajuan peradaban umat manusia. Sepanjang keberadaannya, Islam telah membangun peradaban besar yang sudah memberikan sumbangan yang sangat mementukan dalam sejarah peradaban umat manusia hingga ke zaman kita sekarang ini. Demikian pula sumbangannya dalam rangka mengakui dan menghormati harkat dan martabat manusia atau HAM. Tidak berlebihan kiranya, jika kita mengatakan Islam adalah agama kemanusiaan likulli qaman wa likulli makan.

Hubungan internasional dalam Islam didasarkan pada sumber-sumber bemormatif tertulis dan sumber-sumber praktis yang pernah diterapkan umat Islam dalam sejarah. Sumber normatif tertulis berasal dari Al-Quran dan hadis Rasulullah Saw. Dari kedua sumber ini kemudian ulama menuangkannya ke dalam-kajian fiqb al-sijar wa aljibad (hukum internasional tentang damai dan perang). Istilah. "siyar" untuk kajian hubungan internasional dalam Islam ini, menurt Syarifuddin Pirzada, dipergunakan pertama kali oleh Imam Abu Hanifah. $^{7}$

Islam dalam konteks ini menurut beberapa penulis mempunyai peluang untuk memberikan pembacaan berbeda terhadap studi Hubungan Internasional dan HAM guna memberikan suatu alternatif wacana yang akan ikut mewarnai kajian interdisipliner. Memang bukan merupakan suatu "pekerjaan" mudah untuk bisa memasukkan wacana ini ke dalam ranah arus utama yang selama ini mendominasi. Bahkan untuk sesuatu yang selama ini dianggap "mustahil" dalam ilmu pengetahuan yang berkiblat ke Barat yaitu "intervensi" ranah

7 Anonym, "Dasar-dasar Hubungan Internasional dalam Islam", dikutip dari htt://zairifblog.blogspot.com/2011/01/dasar-dasar-hubungan-intemasional.html diunduh 9 November 2012. 
teologis yang dianggap "najis". Tetapi berangkat dari suatu nilai bersama bahwa setiap ilmu itu pada hakekatnya netral, maka penulis mencoba untuk melakukan - suatu aktivitas akademis yang tergolong kegiatari perintis meskipun Fox dan Sandler (2006) telah mendahului penulis tetapi kedua scholar tersebut hanya melakukan eksplorasi àtas kaitan agama dan studi Hubungan Internasional dan menitikberatkan pada bagaimana agama (Islam) memberikan konstribusi terhadap studi ini dalam perumusan dan penemuan solusi atas berbagai problematika global yang hingga detik ini masih menggunakan "ramuan" Barat dengan sistem trial and error. ${ }^{8}$

Di era modern dilihat dari model berfikirnya umat Islam terpola menjadi dua bentuik pemikiran, yaitu 'moderat dan fondamentalis' dalam menghadapi issu tentang konsep hubungan internasional yang secara ontologis tidak dapat lepas dari pandangannya tentang negara, sehingga dari dua pola ini kalau dihubungkan dengan teori hubungan internasional yang konvensional akan bermuara pada 'liberalis dan realis'.

Munculnya perbedaan seperti ini tidak dapat lepas dari cara memahami teks atau nas yang menjadi dasát pengambilan atau sebagai sumber. Namun ada yang tidak dapat ditinggalkan dalam Islam nilai-nilai dasar yang harus dipertahankan oleh siapaun termasuk negata, yakni: kepentingan atau kemaslahan agama; jiwa; akal; keturunan; dan, harta. Sedang menurut teori kontemporer seperti yang dikemukakan oleh K.H. Sahal Mahfudz selain kelima di atas ditambah satu lagi, yaitu kepentingan lingkungan.

Etika Islam dalam Hubungan Internasional dan HAM, sebagaimana dikemukakan oleh jumhur (mayoritas) ulama membagi dunia menjadi dua, yaitu Darul Islam dan Darul Harbi. ${ }^{9}$ Darul Islam adalah negara-negara yang berdasarkan syari at Islam; negara yang penduduknya beragama Islam dan dapat

${ }^{8}$ Anonym, "Mengkaji Kembali Identitas Studi Hubungan Intemasional dari Perspektif "Teologis: Sebuah Pembacaan Awal", dikutip dari bustomintmengugat.blogspot.com/.../mengkajikembali-identitas-studi.. diunduh 7 Nopember 2012.

"T.M. Hasbi Ash-Shiddieqy, Huksm Antar Golongan Dolam Fiqih Islam, Jakarta: Bulan Bintang, 1971, Cet. 1), hal. 16-18. Banding Bassam Tibi, "War and Peace in Islam", dalam 'Terry Nardin ed., The Ethics of War and Peace Religious And Secular Penpectives, (New Jercey: Pmceton University Press, 1993), hal, 129. 
melaksanakan hukum Islam; negara yang semua penduduknya atau mayoritas beragama Islam; negara-negara yang dikuasai oleh negara Islam walaupun mayoritas penduduknya bukan beragama Islam; negara yang diperintah dan . dikuasai bukan oleh umat Islam tetapi penduduknya yang bergama Islam dapat menjalankan hukum Islam dan tidak ada yang menghalang-halangi untuk melaksanakan hukum tersebut. Darul Harbi mencakup semua negara yang bukan Islam; atau tidak nampak di dalamnya hukum Islam, meskipun yang bermukim di negara itu adalah penduduk yang beragama Islam tetapi hukum Islam tidak dapat dilaksanakan.

Dengan pembagian seperti ini untuk hubungan internasional dan HAM bagi kelompok moderat adalah bukan berarti mengharuskan bahwa Darul Islam itu diperintah satu pemerintahan, demikian pula pada Darul Harbi. Dalam hal ini bahwa segenap umat Islam di seluruh dunia merupakan satu tangan tertuju pada yang satu, dalam satu politik; ini dapat tercapai kalau semua negara Islam dikuasai oleh satu pemerintahan, dan ini tidak realistis artinya tidak mungkin. Dan yang mungkin dapat dilaksanakan adalah terbentuknya banyak negara yang terkualifikasikan sebagai Darul Islam. Dengan demikian membagi dunia menjadi Darul Islam dan Darul Harbi bukan untuk menjadikan dunia ini di bawah. dua pemerintahan dan poltik, tetapi untuk penerapan hukum yang berlaku bagi kedua macam warga negara, artinya dengan banyaknya negaranegara Islam tidaklah menghalangi diterapkan hukum 'Islam. ${ }^{10}$ Bagaimana selanjutnya dengan ketentuan bahwa Syari'at Islam itu 'Alamiyah (Internasinal) bukan Iqlimiyab (Nasional), artinya syari'at Islam harus berlaku untuk seluruh dunia, tidakkah bertentangan dengan yang telah disebutkan di atas? secara teoretis (ilmiyah) Syari at Islam adalah syari'at "alamiyah, akan tetapi pada tingkat pelaksanaan dan penerapannya merupakan syari at iqlimiyyah yang hanya diterapakan pada negara-negara yang masuk dalam Darul Islam. ${ }^{11}$

10Ibid, hal. 30, dan T.M. Hasbi ash-Shiddieqy, Siyasab Sjar'jyab Fiqb Dualy, Jogjakarta: Mudah, t.t.), hal. 19-20.

"Ibid., hal. 1-2. 
Oleh karena itu Darul Islam lahir atas dasar kebangsaan (Nation) yang dibangun atas dasar Islam (agama) dan perjanjian. Dengan kata lain dasar kebangsaan dalam Darul Islam adalah Islam dan berjanji mengikuti hukumnya. ${ }^{12}$

Darul Islam dan kebangsaan di atas adalah sejalan dengan pernyataan ArRagib al-Asfahani, ketika beliau menjelaskan tentang pengertian kata Ummab (bangsa) dalam al-Qur'an, yaitu "tiap-tiap kelompok yang dihimpun oleh sesuatu, baik sesuatu itu berupa agama, waktu maupun tempat yang sằtu; baik pengelompokan itu terjadi secara paksa ataupun atas kehendak sendiri". ${ }^{13}$ Jumlah secara individu yang disebut sebagai umat, al-Qur`an tidak membatasinya. ${ }^{14}$

Dengan demikian Darul Islam dan Kebangsaan adalah sejalan dengan yang dipraktekkan Rasulullah SAW dalam•membangun negara Madinah. Negera Madinah kata Ibnu Kasir dibangun di atas kondisi Ta adudi (pluralisme) adalah relitas sosial politik yang merupakan pilihan Rasulullah SAW. sebagai pondasi hidup negara. Pluralisme politik pertama kali dikenalkan Rasulullah SAW. pada periode hijrah ketika ia mengadakan sebuah perjanjian yang merupakan kontrak sosial-politik dengan elemen-elemen masyarakat Madinah yang cukup varian. Perjanjian tersebut dikenal dengan Sabifab Madinah (Konstitusi Madinah). ${ }^{15}$ Konsep mengenai negara dengan model ini (City-State jika tidak dapat dikatakan Nation-State). Dalam Konstitusi Madinah yang menjadi ikatan sosial yang kokoh dalam bentuk sebuah perjanjian, Nabi menekankan atti penting konsep 'zmmah'. Konsep ini tidak hanya memungkinkan pentingnya kehidupan yang menghargai pluralitas, akan tetapi menempatkan Isiam sebagai rahmatan lil alamin bagi kelangsungan kehidupan umat manusia di muka bumi ini. ${ }^{16}$

${ }^{12}$ T.M. Hasbi Ash-Shiddieqy, Hukum Antar Golongan Dalam Figib Islam, hal. 45;

${ }^{13}$ Ar-Ragib Al-Asfahani, Mu jam Mufradat Alfaz al-Our'an, (Beirut: Dar Al-Fikr, t.t.) hal. 19.

${ }^{14}$ M. Quraish Shihab, Wawasan al-Qur'an, (Bandung: Mizan, 1996), hal. 335.

"Ibnu Kasir, Al-Bidajab wa al-Nibayah, (Beirut:" Maltabah Ma arif, t.t.) hal. 224-26. dan lihat "Multiculturalism" dalan Andrew Heywood, Politics, (New York: Palgrave Macmillan, 2002 ed. ke-2 hal. 119.

${ }^{16}$ Abd. Salam Arif, "Politik Islam antara Aqidah dan Keluasaan Negara', dalam A.Maftuh Abegebril, A. Yani Abevero, Negara Tuban The Thentatic Engrolopaedia, (Yogyakarta: SR-Ins Publishing, 2004), hal.19. 
Menurut Mongomery Watt, istilah 'ummah' berasal dari bahasa Ibrani yang berarti suku bangsa atau bisa juga berarti masyarakat. ${ }^{17}$ Dalam hal yang sama juga dapat dilihat pada Perjanjian Rasulullah dengan golongan Kristen Najtan:

"Dari Muhammad Sang Nabi kepada Abu Harist, uskup Najran, pendeta-pendeta, rahib-rahib, orang-orang yang hidup di gereja-gereja mereka dan budak-budak mereka; semunya akan berada dibawah lindungan Allah dan nabinya; tidak ada uskup yang diberhentikan dari keuskupannya, tidak ada tahib yang yang akan diberhentikan dari biaranya dan tidak ada pendeta yang akan diberhentikan dari posnya, dan tidak akan terjadi perubahan dalam hak-hak yang mereka telah nikmati sejak lama."

- Model di atas diteruskan oleh Abu Bakar as-Shidiq ketika mengirim ekspedisi pertama ke negri Syam:

Hendaklah kamu bersikap adil. Jangån patahkan keyakinan yang telah kamu ikrarkan. Jangan memenggal seseorangpun. Jangan bunuh anak-anak, laki-laki dan perempuan. atau membakar pohon-pohon kurma, dan jangan tebang pohonpohon yang menghasilkan buah-buahan. Jangan bunuh domba-domba, temakternak atau unta-unta, kecuali untuk sekedar dimakan. Mungkin sekali kamu akan bertemu dengan orang-orang yang telah mengundurkan diri ke dalam biara-biara, maka biarkan mereka dan kegiatan mereka dalam keadaan yang damai.

Melihat konteks di atas bagi kelompok moderat hubungan internasional adalah atas dasar Prinsip hubungan ini baik dengan sesama negara Islam maupun bukan negara Islam adalah perdamain, sebagaimana diungkapkan dalam kaidah yang berbunyi sebagai berikut:

$$
\text { في العلاقة هو السلم لأصهال }
$$

(Hukum dasar dalam hubungan antat bangsa adalah perdamaian). ${ }^{18}$

Perdamaian adalah salah satu prinsip yang sangat penting dalam Islam karena merupakan salah satu HAM, sebagaimana dikemukakan al-Qur'an dalam surat al-Anfal (8): 61:

$$
\text { وإن جنحوا للنسم فاجنح لها وتوكل على الله إنه هو النسميع العليم }
$$

17W. Montgomery Watt, Islamic Political Thoubt, (Ediburg: University Press, 1968) hal. 9-10. ${ }^{18}$ Hasbi, Hukum Antar Golongan Dalam Fiqih Islam, hal. 118. 
"Dan jika mereka condong kepada perdamaian, maka condonglah kepadanya dan bertawakallah kepada Allah. Sesungguhnya Dialah Yang Maha Mendengar lagi Maha Mengetahui".

Prinsip yang mengedepankan perdamaian dalam segala aspek kehidupan merupakan suatu hal yang dianjurkan dan bahkan diperintahkan. Dengan prinsip perdamaian ini, masyarakat bisa tentram dan damai serta setiap individu juga akan dapat hidup secara damai. Dan jika mereka condong kepada perdamaian, maka condonglah kepadanya dan bertawakallah kepada Allah. Sesungguhnya Dialah Yang Maha Mendengar lagi Maha Mengetahui. Hubungan Internasional adalah didasarkan dengan perdamaian seperti ini, sejalan atau mirip dengan Hubungan Internasioal sebagaimana yang dikemukakan oleh kalangan Liberalisme Sosiologis ialah, hubungan antara orang yang lebih koperatif dan mendukung perdamaian. Dan juga sebagaimana dikatakan oleh Karl Deutsch yang dikutip oleh Robert Jackson \& .Georg Sorensen, hubungan antar masyarakat yang mampu menghasilkan perdamaian yg lebih dari sekedar ketiadaan perang. Menghasilkan security community dalam mana konflik dan persoalan dapat diselesaikan tanpa harus menggunakan kekerasan fisik dalam sekala besar (perang). ${ }^{19}$

Kata as-Silm pada surat al-Anfal ayat: 8 di atas jika dilihat dari dimensi munasabah (disesuaikan/ dikaitkan?) dengan ayat-ayat lain yang di dalamnya menyebut kata as-Silm, ${ }^{20}$ dapat dipahami bahwa disamping sistem kepercayaan, Islam juga metupakan sistem peradaban yang memadukan antara materi dan spiritualitas. Merujuk pada uraian di atas, peradaban manusia yang damai dan menemukan kebahagiaan yang jelas menjadi bagian dari yang dicita-citakan Islam. Oleh karenanya, Islam sangat memberikan apresiasi yang positif kepada umatnya yang berhasil membangun peradaban manusia menjadi umat penengah (ummatan wasatan). Allah Swt. dalam hal ini berfirman pada surat Aj-Baqarah ayat: 143 sbagai berikut:

${ }^{19}$ Robert Jackson \& Georg Sorensen, Pengantar Studi Habungan Internasional, hal. 144.

${ }^{20}$ Hamim Ilyas, "Akar Fondamentalisme Dalam Diskursus 'Tafsir Al-Qur'an", dalam Makalah Seminar Moslem Scholars Congress, (Yogyakarta, 2004), hal. 6. 
"Demikianlah, kami menjadikan kamu sebagai umat tengah agar kamu menjadi saksi atas manusia dan agar Rasul menjadi saksi atas kamu."

Ummatan Wasatan, menurut Quraish Shihab adalah umat moderat yang posisinya berada di tengah, sehingga dapat dilihat semua pihak dan dari segala penjuru. Dengan posisinya yang berada di tengah, menyebabkan mereka tidak hanyut dalam materialisme dan tidak membumbung tinggi ke alam rohani. Posisi tengah (moderat) telah menjadikan mereka mampu memadukan aspek rohani dan jasmani, materiel dan spiritual dalam sgala sikap dan aktivitas. ${ }^{21}$ Menurut Azyumardi, Ummatan Wasatan adalah umat yang toleran, inllusif, dan menjunjung tinggi nilai-nilai kemanusiaan dan keadilan, Muslim yang demikian senantiasa-berupaya menafsirkan Islam untuk merespon secara lebih efektif berbagai realitas keagamaan, sosial bahkan urusan internasional. Mereka berusaha mengamalkan ajaran Islam secara lebih baik; hidup dan bekerja dan mendorong perubahan dari lapisan masyarakat lapisan bawah, menolak ekstrimisme atas nama -agama, dan meyalini bahwa terorisme (bertindak melanggar HAM) tidak sah menurut ajaran Islam. ${ }^{22}$

Dengan kemampuan membangun posisi moderat seperti itu, maka kekuatan militer bukan merupakan pertimbangan utama (menghindari penggunaan kekerasan dan mengutamakan diplomasi), hanya dapat dilakukan bilamana dalam kondisi darurat. ${ }^{23}$ Oleh karena itu prinsip Hubungan Internasional dalam Islam adalah Perdamaian yang abadi sebagaimana anjuran àlQuran pada Surat al-Baqarah: 200, an-Nisä : 90;94 dan at-Taubah: $36 .{ }^{24}$ Dan

"M. Quraish Shihab, IVavasari.., hal. 325.

22Azyumardi Azra, "Islam dan Politik Luar Negeri", dikutip dari http: //ww.cmm.or.id/cmm-ind_more.php?id=A3385_03_0_M diunduh 2012.

${ }^{23}$ Hasbi, Hukum Antar Golongan Dalam Fiqib Islam, hal. 118.

${ }^{24} \mathrm{Ibid}$. Dan lihat an-Nisa: 90 dan 94 "Kecuali orang-orang yang meminta perlindungan kepada sesuatu kaum, yang antara kamu dan kaum itu telah ada perjanjian (damai) atau orangorang yang datang kepada kamu sedang hati mereka merasa keberatan untuk memerangi kamu dan memerangi kaumnya. Kalau Allah menghendaki, tentu Dia memberi kekuasaan kepada mereka terhadap kamu, lalu pastilah mereka memerangimu. Tetapi jika mereka membiarkan kamu, dan tidak memerangi kamu serta mengemukakan perdamaian kepadamu maka Allah tidak memberi jalan bagimu (untuk menawan dan membunuh) mereka. "Hai orang-orang y'ang beriman, apabila kamu pergi (berperang) di jalan Allah, maka telitilah dan janganlah kamu mengatakan kepada orang yang mengucapkan "salam" kepadamu: "Kamu bukan seorang 
pendapat ini sejalan dengan Jumhur Ulama Muhaqiqin, menetapakan bahwa dasar pokok hubungan antara Islam dengan lainnya adalah Perdamaian, selanjutnya golongan ini mengatakan bahwa hubungan antara dua golongan yang bermusuhan atau berperang dan berpegang pada peperangan, pada kenyataannya tidak. dapat dipandang sebagai dasar agama dan bersifat sementara. ${ }^{25}$ Andaikata peperangan adalah seșuatu yang harus dilakukan maka perang dalam Islam adalah perang pertahanan, yang bertujuan untuk menolak serangan dan pengamanan pelaksanaan dakwah. Perang harus berhenti jika maksud yang dituju telah tercapai. Apabila serangan musuh telah berhenti dan mereka cenderung kepada perdamaian, maka kaum muslimin harus menerima perdamaian tersebut, baik dalam bentuk gencatan senjata atau dalam bentuk pembuatan perjanjian. Dan ketika peperangan sedang berlangsung, para prajurit tidak dibolehkan membunuh kaum wanita, anak-anak, dan orang tua. Selain itu, tidak dibenarkan mencincang mayat-mayat musuh, malah wajib menutup auratnya. Ketika perang telah usai, maka semua mayat wajib dikuburkan sebagai penghormatan kemanusia

Pengkategorian negara menjadi Darul Islam dan Darul Harbi tidak merusak prinsip hubungan dengan perdamaian, karena prinsip damai tidak memandang suatu negara sebagai Darul Islam, Darul Harbi dan Darul 'Abdi atau tidak, kecuali Darul Harbi tersebut melanggar negara Islam secara langsung. Prinsip damai adalah prinsip yang sesuai dengan prinsip Islam sebagaimana jiwa al-Qur ${ }^{2}{ }^{20}{ }^{26}$ Dalam teori Hubungan Internasional perdamaian termasuk di antara nilai hubungan internasional yang paling fondamental. Bagi penganut libralisme

mukmin" (lalu kamu membunuhnya), dengan maksud mencari harta benda kehidupan di dunia, karena di sisi Allah ada harta yang banyak Begitu jugalah keadaan kamu dahulu, balu Allah menganugerahkan nikmat-Nya atas kamu, maka telitilah. Sesungguhnya Allah Maha Mengetahui apa yang kamu kerjakan." at-'Taubah: 36 "Hai orang-orang yang beriman, apabila kamu pergi (berperang) di jalan Allah, maka telitilah dan janganlah kamu mengatakan kepada orang yang mengucapkan "salam" kepadamu: "Kamu bukan seorang mukmin" (lalu kamu membunuhnya), dengan maksud mencari harta benda kehidupan di dunia, karena di sisi Allah ada harta yang banyak. Begitu jugalah keadaan kamu dahulu, laiu Allah menganugerahkan nikmat-Nya atas kamu, maka telitilah. Sesungguhnya Allah Maha Mengetahui apa yang kamu kerjakan."

${ }^{25}$ Hasbi, Hulam Antar Golongan..., hal. 119.

${ }^{25}$ Ibid., hal. 121. 
pendekatan ini memjadi ciri khasnya, bahwa pendekatan ini bergerak pada asumsi bahwa hubungan internasional dapat dicirikan sebagai dunia dimana negara-negara bekerjasama satu sama lain untuk memelihara perdamaian dan kebebasan serta mengejar perubahan progresif. ${ }^{27}$

Untuk itu menjaga perdamaian sebagai sebuah keniscayaan, karena masingmasing negara (Islam) mempunyai kebangsaan sendiri, maka hal itu janganlah membawa asabah jahiliyah, mereka harus mempunyai suatu lembaga persatuan seperti PBB. sekarang ini, ${ }^{28}$ yang dibangun dengan melalui perjanjian. Perjanjian yang dibuat adalah perjanjian untuk mengokohkan perdamaian dan mengakhiri peperangan agar tidak terjadi pelanggaran HAM setelah itu, atau menghindari pelanggaran di masa yang akan datang, bukan perjanjian yang membawa kemadaratan,yang demikian sesuai dengan kaidah:

$$
\text { كل صبلح جائزالا مهلحا أنحل حرما او حرم حلالا }
$$

Artinya: "Semua perdamaian itu boleh kecuali petdamaian yang menghalalkan yang hatam dan mengharamkan yang halaI." 29

Kedua belah pihak tidak boleh melakukan kecurangan, penipuan, atau memutarbalikkan iși perjanjian. Contoh perjanjian yang telah dipraktekkan oleh Rasulullah adalah Piagam Madinab dan Perjanjian Hudaibiyah. Perjanjian tentang perdamaian ini harus dipenuhi terkecuali musuh mengkhianati atau ada tandatanda mengkhianati tidak boleh menerimanya, selama perjanjian tersebut tidak mengandung kezaliman tidak ada alasan untuk menolak. ${ }^{30}$

Sedang bagi kelompok fondamentalis yang mempunyai tradisi interpretasi sosio-religius yang menjadikan Islam sebagai agama dan ideologi artinya yang dikembangkan di dalamnya tidak hanaya doktrin-doktrin teologis, tapi juga ideologis. Doktrin ini dalam sejarahnya dikembangkan oleh tokoh-tokoh pendiri fondamentalis modern, yakni Hasan al-Bana, Abu A la al-Maududi, Sayyid Qutub, Sa id Hawa, melihat negara seperti yang dikemukakan oleh

\footnotetext{
27Robert Jackson \& Georg Sotensen, Pengantar Studi Hubungan Intertasional, hal.6. ${ }^{28}$ Hasbi, Hukeum Antar Golongan, hal. 124.

29Ibid., hal. 132-133.

30Ibid, hal. 136-137
} 
Sayyid Qutb, dunia terdiri dari Darul Islam Darul Harb, "dunia orang beriman” dan "dunia neo jahilliyah". Perang melawan orang kafix adalah kewajiban bagi setiap muslim. Ini adalah persoalan kafir atau beriman, jahilliyyah atau Islam? Qutb yakin bahwa konfrontasi antara Islam dan masyarakat jahilliyah internasional akan diakhiri dengan kemenangan kaum muslimin, tatanan politik di semua negara termasuk negara Muslim bersifat anti-Islami, dan aktifis Islam harus menggantikan sistem politik jahiliyah tersebut. Sejalan dengan ini Abu A la al-Maududi mengatakan kaum muslim harus menggunakan segală sarana yang tersedia untuk melawan jahiliyah moderen, dan diperkuat oleh Hasan alBanna, bahwa Islam menentang sekularisme dan pembatasan Islam sebagai urusan pribadi.

Seperti ungkapan Hasan al Banna, jihad adalah kewajiban setiap muslim. "Diwajibkan atas kamu berperang, padahal berperang itu adalah sesuatu yg kamu benci." (al-Qur'an S. 2: 216) "Dan sungguh jika kamu meninggal atau gugur, tentulah kepada Allah saja kamu dikumpulkan.” (al-Qur`an S. 3: 158). Al Banna mengagungkan perang (qital) sebagai bentuk jihad yang mulia (jihad akbar). Jihad dilakukan dengan kekerasan terhadap orang kafir maupun kaum muslimin yang dicurigai sebagai Muslim nominal (KTP).Tampaknya pesan toleransi ini disembunyikan dari para pengikut Hasan Al Banna. Dengan demikian kelompok fondamentalis dalam hubungan internasional lebih dekat mencerminkan cara pandang real-politik (realis).

\section{Penutup}

Sebagai akhir deskripsi, penjelasan, analisis dan diskusi yang telah dikemukakan dari keseluruhan tuilisan ini, dapat disimpulkan sebagai berikut:

1. Bahwa negara dalam Islam dibagi terdiri dari dua yaitu Darul Islam dan Darul Harbi, dengan pembagian negara menjadi dua sebagaimana tersebut di atas bukan berarti mengharuskan bahwa Darul Islam itu diperintah satu pemerintahan.

2. Bahwa Darul Islam lahir atas dasar kebangsaan (Nation ?) yang dibangun atas dasar Islam (agama) dan perjanjian yang selalu menghormati HAM. 
Dengan kata lain dasar kebangsaan dalam Darul Islam adalah perjanjian yang menjunjung nilai-nilai keanusiaan..

3. Bahwa prinsip hubungan internasional dalam. Islam adalah perdamaian yang abadi yang merupakan hak asasi setiap bangsa, kecuali pada kondisi daruri, maka hubungan internasional berubah menjadi perang dan hanya bersifat sementara. Aridaikata peperangan adalah sesuatu yang harus dilakukan maka perang dalam Islam adalah perang pertahanan, yang bertujuan untuk menolak serangan dan pengamanan pelaksanaan dakwah-dan tidak merubah kebijakan pokok, yaitu tetap pada dalam hubungan perdamaian.

\section{DAFTAR PUSTAKA}

Abegebril, A.Maftuh dan A. Yani Abevero. 2004. Negara Tuban The Thematic Engyclopaedia. Yogyakarta: SR-Ins Publishing.

Asfahani, Ar-Ragib Al-. Tanpa Tahun. Mu'jam Mufradat alfą al-Qur'an. Beirut: Dar Al-Fikr.

Azra, Azyumardi. Islamdan Politik Laar Negeri,.Negeri, http://ww.cmm.or.id/cmm-ind_more.php?id=A3385_03_0_M.

Heywood, Andrew. 2002. Politics. New York: Palgrave Macmillan.

Ilyas, Hamim.2004. Akar Fondamentalisme dalam Diskursus Tafsir Al-Qur'an. Makalah Seminar Moslem Scholars Congress, Yogyakarta.

Jackson, Robert \& Georg Sorensen. 2005. Pengantar Studi Hubungan Internasional, . alih bahasa Dadan Suryaputra. Yogyakarta: Pustaka Pelajar.

Kasir, Ibnu. Tanpa Tahun. Al-Bidayah wa al-Nibayah. Beirut: Maktabah Ma'arif.

Khallaf, Abd. Wahab. 1977. As-Siyasab as-Syar ¿iyah. Kairo: Dar al-Ansar.

Manzur, Ibnu. 1386/1968. Lisanul 'Arab. Beirut: Dar as-Sadir.

Shiddieqy, T.M. Hasbi Ash-. Tanpa Tahun. Siyasab Sjarizyab Fiqh Dualy. Jogjakarta: Mudah. 
Shiddieqy, T.M. Hasbi Ash-. 1971. Hukum Antar Golongan Dalam Fiqib Islam. Jakarta: Bulan Bintang.

Shiddiqy, Nourouzzaman.1987. "Muhammad Hasbi Ash-Shiddieqy Dalam Perspektif Sejarah Pemikiran Islam di Indonesia", desertasi Doktor, Yogyakarta: Institut Agama Islam Negeri Sunan Kalijaga.

Shihab, M. Quraish. 1996. Wawasan al-Qur'an. Bandung: Mizan.

Tibi, Bassam.1993. "War and Peace in Islam" dalam Terry Nardin' ed., The Ethics of War and Peace Religious And Secular Perspectives. New Jercey: Prnceton University Press.

Watt, W. Montgomery.1968. Islainic Political Thought. Ediburg: University Press. 